\title{
PERKAWINAN BEDA AGAMA DI TINJAU DARI UNDANG-UNDANG NOMOR 1 TAHUN 1974 TENTANG PERKAWINAN DAN HUKUM ADAT DI BALI (STUDI KASUS DI DESA TANGGUWISIA KECAMATAN SERIRIT KABUPATEN BULELENG)
}

\author{
I Nengah Suastika \\ Jurusan Pendidikan Pancasila dan Kewarganegaraan \\ Universitas Pendidikan Ganesha \\ Email: suastikainengah08@gmail.com
}

\begin{abstract}
ABSTRAK
Penelitian ini bertujuan untuk (1) mengetahui latar belakang terjadinya perkawinan beda agama di Desa Tangguwisia, Kecamatan Seririt, Kabupaten Buleleng, (2) untuk mengetahui prosedur dari perkawinan beda agama di tinjau dari UU No 1Tahun 1974 yang terjadi di Desa Tangguwisia, Kecamatan Seririt, Kabupaten Buleleng, (3) untuk mengetahui bagaimana dampak serta pandangan masyarakat mengenai perkawinan beda agama terhadap pasangan yang melakukan perkawinan tersebut. Penelitian ini adalah termasuk penelitian Deskritif Kualitatif. Subyek dalam penelitian ini adalah pelaku perkawinan beda agama, tokoh agama, generasi muda, dan tokoh masyarakat. Penentuan responden yang di tentukan dengan metode purposive sampling. Pengumpulan data menggunakan metode wawancara, observasi, pencatatan dokumen, kepustakaan. Hasil penelitian menunjukkan bahwa perkawinan beda agama yang terjadi di desa tangguwisia bisa dilakukan apabila terlebih dahulu melaksanakan upacara sudi wadani, sudi yang artinya penyucian, wadani yang artinya ucapan -ucapanpernyataan berupa kata-kata, jadi sydi wardani adalah upacara pada waktu melakukan penyucian, menjadi agama hindu. Yang melatar belakangi terjadinya perkawinan beda agama adalah karena meningkatnya hubungan sosial anak-anak dari pulau-kepulau dan juga dari manca negara .Perkawinan dilaksanakan berdasarkan atas hukum adat di bali sah nya perkawinan menurut yurisprudensi raad kerta dan adat bali apabila sudah melaksanakan upacara mebyakaon penyucian kedua belah pihak pasangan mempelai, prosedur perkawinan sesuai dengan hukum adat bali calon mempelai yang non hindu arus melaksanakan sudi wadani untuk memeluk agama hindu. Perkawinan beda agama berdampak psikologis, pewaris, status anak, akibat ekonomi pandangan masyarakat $80 \%$ setuju dengan perkawinan beda agama terjadi karena telah mentaati awig-awig umat hindu dengan melebur agama yang dahulu melakukan sudi wadani untuk memeluk agama sama dengan mempelai pria. Karena dalam umat hindu perkawinan yang memiliki keyakinan beda tidak dapat dilangsungkan perkawinan tersebut.
\end{abstract}

Kata kunci : Perkawinan Beda Agama, Ditinjau Dari UU No 1 Tahun 1974 Dan Hukum Adat Bali Di Desa Pakraman Tangguwisia

\footnotetext{
ABSTRACT

This study aims to (1) determine the background of the interfaith marriage in the village Tangguwisia, District Seririt, Buleleng, (2) to determine the procedure of interfaith marriage in the review of Law No. 1 year 1974 occurred in the village Tangguwisia, District Seririt, Buleleng, (3) to find out how the impact and community perceptions of interfaith marriage to couples who perform the marriage. This study is included Descriptive Qualitative research. The subjects in this study were the perpetrators of interfaith marriage, religious leaders, youth, and community leaders. Respondent is determined by purposive sampling method. Collecting data using interviews, observation, recording of documents, literature. The results showed that interfaith marriage that occurred in the village of tangguwisia be done if the first ceremony wadani willing, willing the means of purification, which means utterance wadani -ucapanpernyataan form of
} 
words, so sydi wardani is a ceremony at the time of purification, into a religion Hindu. The background for the interfaith marriage is due to the increase of social relationships the children of the island-kepulau and also from foreign countries .Perkawinan implemented based on customary law in bali his lawful marriages under customary jurisprudence raad kerta and bali when they implement second purification ceremony mebyakaon parties for the couple, the marriage procedure in accordance with customary law bali non hindu bride who carry currents wadani willing to embrace Hinduism. Psychological impact on interfaith marriage, the heir, the child's status, due to the economic views of the community $80 \%$ agree with interfaith marriage happened because they had complied awig awig Hindus by religion practicing melt wadani willing to embrace the same with the groom. Because the Hindus marriage have different beliefs can not be held the marriage.

Keywords: Interfaith Marriages, Seen From Law No. 1 of 1974 and Customary Law Bali Di Pakraman Tangguwisia

\section{PENDAHULUAN Latar Belakang}

Persoalan perkawinan adalah persoalan yang selalu aktual dan selalu menarik untuk di bicarakan, Karena persoalan ini bukan hanya menyangkut tabiat dan hajat hidup manusia saja, tetapi juga menyentuh suatu lembaga yang luhur, yaitu rumah tangga. Luhur, karena lembaga ini merupakan benteng bagi pertahanan martabat manusia dan nilainilai martabat kehidupan yang luhur. Perkawinan merupakan salah satu fase sangat penting bagi hidup manusia dalam bermasyarakat, mengapa dikatakan sangat penting karena perkawinan dapat mengubah status hukum seseorang. Semula manusia dianggap belum dewasa dan dengan dilangsungkannya perkawinan, dapat menjadi dewasa atau yamg semula dianggap anak muda dengan adanya perkawinan akan menjadi suami istri dengan berbagai konsekuensi yuridis dan sosiologis yang menyertainya (Wayan windia. 2009:1).

Berbicara mengenai perkawinan, perkawinan bertujuan untuk membentuk rumah tangga yang bahagia, perkawinan juga menyangkut kelangsungan hidup dari manusia. Hidup bersama antara seorang pria dengan seorang wanita tersebut mempunyai akibat yang sangat penting dalam masyarakat, baik terhadap kedua belah pihak maupun terhadap keturunannya serta anggota masyarakat lainnya. Perkawinan tentunya tidak terlepas dari Undang-Undang No 1 Tahun 1974 yang menjelaskan bahwa perkawinan adalah ikatan lahir batin antara seorang pria dengan seorang wanita sebagai suami-istri dengan tujuan membentuk keluarga bahagia dan kekal berdasarkan Ketuhanan Yang Maha Esa, dan juga bertujuan untuk meneruskan dan melanjutkan keturunan keluarga. Dalam pasal 2 Undang-undang No 1 tahun 1974 di nyatakan bahwa perkawinan itu sah apabila dilaksanakan sesuai dengan hukum masing-masing agama dan kepercayaan serta setiap perkawinan harus tercatat sesuai dengan aturan perundang-undangan yang berlaku, berkenan dengan hal seperti itu maka perkawinan di dalam masyarakat hindu khususnya dan masyarakat bangsa indonesia umumnya sesuai dengan hukum masing-masing agama dan kepercayaan yang dianutnya.

Dalam perundang-undangan di indonesia, perkawinan beda agama didefisinikan dalam undang-undang No 1 Tahun 1974 Di dalam kondisi masyarakat Indonesia yang beragam, dari segi suku, agama, dan ras, terdapat berbagai macam masalah yang timbul di dalamnya. Seperti misalnya masalah di dalam pembagian harta warisan dalam keluarga, masalah mengenai jenis adat apa yang berlaku dalam suatu atuaran keluarga.

Salah satu masalah yang menjadi sorotan dalam konflik-konflik yang timbul dalam masyarakat sekarang ini ialah, dimana sering kita jumpai terjadinya pelangsungan Pernikahan Beda Agama. Kalau kita mau meninjau lebih jauh mengenai Negara Indonesia merupakan negara dengan wilayah yang luas dan terbentuk dari ribuan pulau dari Sabang sampai Merauke.Dalam wilayah yang luas dan banyak terpisahkan oleh lautan itu, 
hidup golongan-golongan masyarat yang berbeda latar belakang satu sama lain.

Di dalam kondisi masyarakat Indonesia yang beragam tersebut, baik dari segi budaya, suku, ras, agama, kontak antar satu golongan masyarakat satu dengan yang lain sudah tentu tidak dapat dihindarkan. Kontak antar masyarakat yang berbeda latar belakang ini pada kemudian hari menimbulkan adanya suatu fenomena dalam masyarakat yaitu berupa perkawinan campuran.

Salah satu perkawinan campuran yang paling banyak mengundang perdebatan adalah perkawinan campuran antara pasangan yang memiliki agama yang berbeda. Masalahnya, dengan perkawinan beda agama akan terjadi suatu perbedaan prinsipil dalam perkawinan itu sehingga dikhawatirkan akan menimbulkan berbagai masalah yang rumit untuk diselesaikan di kemudian hari. Oleh karena itu kemudian hal ini banyak mendapat tentangan dari masyarakat luas, tetapi juga oleh hukum positif di negara kita serta hukum agama yang mereka anut. Walau tidak dapat dipungkiri ada saja pihak yang pro terhadap keberadaan perkawinan beda agama ini.

Islam sendiri sebagai agama yang dianut oleh mayoritas penduduk di Indonesia sebenarnya juga menentang keras mengenai keberadaan perkawinan antar agama di dalam masyarakat Indonesia saat ini. Sangat dilarang bagi umat Islam untuk menikahi pasangan yang non muslim. Larangan ini dapat kita jumpai dalam sumber-sumber hukum Islam yang menyebutkannya secara implisit maupun eksplisit.

Dengan adanya berbagai perbedaan pandangan mengenai perkawinan beda agama ini, maka dalam makalah ini tertarik untuk membahas lebih dalam mengenai perkawinan beda agama di Indonesia, terutama dilihat dari perspektif hukum Perdata Indonesia.

Perkawinan beda agama adalah perkawinan antara pria dan wanita yang keduanya memiliki perbedaan agama atau kepercayaan satu sama lain. Perkawinan beda agama bisa terjadi atar wni yang pria wni perempuan wni yang memiliki kepercayaan agama berbeda, kepercayaan juga bisa dengan beda kewarganegaraan yaitu pria dan wanita salah satunya kewarganegaraan asing dan juga salah satunya memiliki perbedaan agama atau kepercayaan.

Pandangan agama hindu perkawinan orang yang beragama hindu yang tidak memenuhi syarat dapat di batalkan. Suatu perkawinan batal karena tidak memenuhi syarat bila perkawinan itu dilakukan menurut hukum hindu tetapi tidak memenuhi syarat untuk mengesahkannya, misalnya mereka yang tidak menganut agama yang sama pada saat upacara perkawinan itu dilakukan, tidak dapat dilakukan menurut hukum agama hindu, apabila salah satu mempelai bukan beragama hindu, maka diwajibkan sebagai penganut agama hindu, karena calon mempelai yang bukan agama hindu tidak di sucikan terlebih dahulu dan kemudian dilaksanakan perkawinan, hal ini melanggar ketentuan dalam sloka V89 kitab manawadharmasasstra, yang berbunyi:

Air pesucian tidak bisa di berikan kepada mereka yang tidak menghiraukan upacara-upacara yang telah di tentukan sehingga, dianggap kelahiran mereka itu sia-sia belaka, tidak pula diberikan kepada mereka yang lahir dari perkawinan campuran kasta secara tidak resmi, kepada mereka yang menjadi petapa dari golongan murtad perkawinan tidak disahkan oleh pendeta.

Dengan demikian adapun ketentuan hukum positif terhadap perkawian beda agama adalah sebagai berikut : di indonesia secara yuridis formal, perkawinan indonesia diatur dalam UU republik indonesia No 1 tahun 1974 tentang perkawinan dan intruksi presiden republik indonesia No 1 tahun 1991 tentang komplikasi hukum islam. kedua produk perundang undangan ini mengatur masalah-masalah yang berkaitan dengan perkawinan termasuk perkawinan antar agama.

Dalam Undang-undang republik indonesia No 1 tahun 1974 tentang perkawinan pasal 2 ayat 1disebutkan perkawinan adalah sah apabila dilakukan menurut hukum masing-masing agamanya atau kepercayaan yang 
dianutnya dalam rumusan ini diketahui bahwa tidak ada perkawinan diluar hukum masing-masing agama dan kepercayaan hal ini senada di terangkan beberapa pasal dalam intruksi presiden republik indonesia nomor 1 tahun 1991 tentang kompilasi hukum islam sebagai berikut: pasal 4 Perkawinan adalah sah, apabila dilakukan menurut hukum Islam sesuai dengan pasal 2 ayat (1) Undang-undang No. 1 Tahun 1974 tentang Perkawinan", Pasal 40: Dilarang melangsungkan perkawinan antara seorang pria dengan seorang wanita karena keadaan tertentu;

a. Karena wanita yang bersangkutan masih terikat satu perkawinan dengan pria lain;

b. Seorang wanita yang masih berada dalam masa iddah dengan pria lain;

c. seorang wanita yang tidak beragam Islam.

Pasal 44: "Seorang wanita Islam dilarang melangsungkan perkawinan dengan seorang pria yang tidak beragama Islam", Pasal 61: " Tidak sekufu tidak dapat dijadikan alasan untuk mencegah perkawinan, kecuali tidak sekufu karena perbedaan agama atau ikhtilaf al-dien".

Dengan demikian, menurut penjelasan pasal-pasal tersebut bahwa setiap perkawinan yang dilaksanakan dalam wilayah hukum Indonesia harus dilaksanakan dalam satu jalur agama, tidak boleh dilangsungkan perkawinan masing-masing agama, dan jika terjadi maka hal tersebut merupakan pelanggaran terhadap konstitusi.

\section{METODE PENELITIAN Jenis Penelitian}

Penelitian ini menggunakan jenis penelitian deskriftif kualitatif dimana melalui penelitian ini, peneliti mendiskripsikan secara deskriptif kualitatif persoalan yang menyangkut perkawinan beda agama ditinjau dari uu no 1 tahun 1974 dan hukum adat bali (studi kasus di desa pakraman tangguwisia, kecamatan seririt kabupaten buleleng).

\section{Subjek Penelitian}

Dalam penelitian ini yang menjadi subjek penelitian adalah orang yang melaksanakan perkawinan beda agama, tokoh-tokoh beda agama, dan tokoh-tokoh masyarakat yang terlibat secara langsung maupun tidak langsung dalam proses perkawinan Beda Agama tersebut khususnya yang ada di Desa Adat Tangguwisia.

\section{Teknik Penentuan Sampel}

Penentuan informan atau responden yang menjadi sumber data dalam hal ini ditentukan secara purposive sampling dimana penentuan sampel sesuai dengan tujuan penelitian (sesuai dengan tujuan) dan ditentukan pula oleh kedudukan informan sebagai pemimpin informal yang memiliki pengaruh dalam menentukan segala sesuatu dalam masyarakat Desa Tangguwisia untuk menentukan responden, maka penelitian menentukan informan kunci (key informan) dan selanjutnya bergulir ke koresponden lain berdasarkan prinsip "snowball sampling", sampai di temukan kejenuhan data yang mana informasi sudah terkumpul secara tuntas (Nasition, 1988:32). Atas dasar pertimbangan tersebut, besaran dan jumlahnya tidak di tentukan sebelumnya, akan tetapi di tentukan oleh tuntutan untuk terkumpulnya informassi dan ketuntasan dalam pemunculan makna realitas alamiahnya.

\section{Teknik pengumpulan data}

1) Metode wawancara adalah pengumpulan data dengan mempergunakan Tanya jawab antar pencari informasi. 2) Metode observasi adalah suatu cara pengumpulan data yang di lakukan oleh peneliti dengan mengamati langsung obyek yang di teliti.3) Metode kepustakaan.4) Metode analisis data.

\section{PEMBAHASAN}

Prosedur perkawinan beda agama Ditinjau dari Undang - Undang No. 1 Tahun 1974 tentang Perkawinan

Dengan berlakunya UndangUndang No. 1 Tahun 1974 tentang Perkawinan, (UU Perkawinan) maka semua perundang-undangan perkawinan Hindia Belanda dinyatakan tidak berlaku lagi. Hal ini secara tegas dinyatakan dalam Pasal 66 UU Perkawinan. Menurut Pasal 1 UU Perkawinan, perkawinan adalah sebuah ikatan lahir bathin antara 
seorang pria dengan seorang wanita sebagai suami isteri dengan tujuan membentuk keluarga (rumah tangga) yang bahagia dan kekal berdasarkan Ketuhanan Yang Maha Esa. Dari pasal ini, tersirat bahwa perkawinan yang berlaku di Indonesia adalah perkawinan antara seorang pria dan wanita saja. Selanjutnya, dalam Pasal 2 Undang-Undang tersebut disebutkan bahwa perkawinan dianggap sah, apabila dilakukan menurut hukum masing-masing agama dan kepercayaan para pihak.

\section{Prosedur Perkawinan Beda Agama} Ditinjau Dari Hukum Adat Bali

Dalam prosedur pelaksanaan perkawinan beda agama di desa tangguwisia perkawinan yang berlangsung sesuai dengan hukum adat dan jika dilihat dalam hukum adat. Pelaksanaan dari pada perkawinan beda agama ada yang melakukan dirumah wanita atau laki-laki akan tetapi lebih banyak yang melangsungkan perkawinannya di rumah laki-laki, sehubungan dengan calon mempelai memeluk keyakinan ber bedabeda maka sangat di perlukan adanya upacara sudi wadani penyucian dan untuk memeluk agama hindu (perpindahan agama). Adapun tata cara dalam pelaksanaan upacara sudi wardani diantanya adalah yang pertama membuat surat pernyataan penyucian yang sah, upacaranya adalah mempergunakan banten mebyakala, maprastiste, dan tataban sesuai dengan kemampuan memper gunakana bhasma air cendana(madya), mempergunakan air, bunga, wija (nista), dan pelaksanaanya selalu disertai dengan api. Kemudian mengucapkan

Om,sa,ba,ta,a,i,na,ma,si,wa,ya,Ang,Ung, Mang,Om.

Dampak dan pandangan masyarakat perkawinan beda agama terhadap pasangan yang melakukan perkawinan tersebut

Dalam suatu ikatan perkawinan atau berumah tangga, tidak semua kehidupan suami istri bisa berjalan dengan lancar dan harmonis seperti apa yang di harapkan dengan pasangan suami istri pada umumnya. Begitu pula dengan pasangan suami istri yang masa mudanya masing-masing berbeda keyakinan (perkawinan beda agama) di desa tangguwisia. Dalam perkawinan ini ada yang masih utuh dan ada pula yang melaksanakan perkawinan dan kemudian cerai. Putusnya suatu perkawinan yang di sebabkan oleh karena adanya perceraian, tentunya akan menimbulkan permasalahan-permasalahan. Adapun dampak dari akibat hukum yang di timbulkan apabila terjadi putusnya perkawinan beda agama, yaitu dampak psikologis, pewarisan, status anak, dan akibat ekonomi.

Dari 10 narasumber yang di wawancarai sebanyak 8 orang yang setuju mengenai perkawinan beda agama yang telah terjadi di desa tangguwisia dengan alasasan sesuai berjalan dengan awig-awig dan sudah melakukan sudi wadani dan upacaranya tidak mengganggu ketentraman masyarat, sedangkan yang lagi 2 orang masyarakat menyatakan kurang setuju dengan adanya perkawinan beda agama dengan alasan yang nantinya akan mempersulit dalam administrasi penduduk yang akan di catat di kantor catatan cipil.

Bangsa Indonesia terdiri dari berbagai macam suku, golongan, ras dan agama serta kaya akan budaya. Heteroginitas masyarakat Indonesia itu sangat memungkinkan terjadinya perkawinan beda agama. Mengenai perkawinan beda agama Perkawinan beda agama, adalah suatu perkawinan yang dilakukan oleh seorang pria sebagai suami dengan seorang wanita sebagai isteri, yang memeluk agama dan kepercayaan yang berbeda antara satu dengan yang lain. Perlangsungan perkawinan beda agama yang terjadi di Desa Pakraman tangguwisia telah dilangsungkan dengan menurut hukum masing-masing. Perkawinan yang di laksanakan telah mematuhi hukum adat dengan malkukan sudhi wadani penyucian diri dan pindah agama berkeyakinan sama pelaksanaan perkawinan di saksikan oleh beberapa saksi dihadapan pencatatan cipil, prajuruprajuru dan pendeta. Dengan adanya penjelasan tersebut diatas maka upacara perkawinan bisa dilaksanakan karena sudah tidak ada yang bertentangan. 


\section{PENUTUP \\ Kesimpulan}

Dengan berlakunya Undang-

Undang No. 1 Tahun 1974 tentang Perkawinan, (UU Perkawinan) maka semua perundang-undangan perkawinan Hindia Belanda dinyatakan tidak berlaku lagi. . Selanjutnya, dalam Pasal 2 UndangUndang tersebut disebutkan bahwa perkawinan dianggap sah, apabila dilakukan menurut hukum masing-masing agama dan kepercayaan para pihak. Setelah perkawinan dilakukan, perkawinan tersebut pun harus dicatatkan, dalam hal ini pencatatan di Kantor Urusan Agama (KUA) dan Catatan Sipil.

Prosedur Perkawinan Beda Agama

Ditinjau dari Hukum Adat Bali, pelaksanaan dari pada perkawinan beda agama ada yang melakukan di rumah wanita atau laki-laki akan tetapi lebih banyak yang melangsungkan perkawinannya di rumah laki-laki, sehubungan dengan calon mempelai memeluk keyakinan ber beda-beda maka sangat di perlukan adanya upacara sudi wadani penyucian dan untuk memeluk agama hindu (perpindahan agama). Dampak dan pandangan masyarakat perkawinan beda agama terhadap pasangan yang melakukan perkawinan tersebut

Dari berbagai pandangan mengenai perkawinan beda agama peneliti kaitkan dengan ajaran weda dan UU no 1 tahun 1974 menyangkut masalah perkawinan dalam Manawa Dharmasastra IX,45(Puja.1978.540) dinyatakan bahwa istri tunggal dengan suaminya. Ini artinya kedudukan wanita dan laki-laki adalah setara dan sangat utama dalam agama hindu. Karena itu di dalam $\mathrm{Rg}$ weda laki - laki dan perempuan yang sudah menjadi suami istri di sebut dengan suatu istilah yaitu DAMPATI artinya tidak dapat di pisahkan. Demikian juga kalau laki-laki yang di sebut dengan suami pasti sudah punya istri tidak ada laki-laki yang bujangan di sebut suami. Mereka di sebut suami dan istri karena mereka sejajar tetapi memiliki beda fungsi.
Saran

Kepada pemerintah, perlu diadakan sosialisasi mengenai betapa pentingnya melakukan pencatatan di kantor catatan cipil untuk membuat akte perkawinan sebagai syarat sahnya perkawinan menurut hukum untuk memperoleh kepastian hukum.

Kepada masyarakat bali khusunya masyarakat yang beragama hindu yang memiliki calon istri non hindu belum menikah maupun sudah menikah jangan lah memiliki suatu anggapan bahwa perkawinan beda agama itu tidak baik dilakukan, atau pun tidak boleh dilakukan, karena perkawinan beda agama setelah melakukan upacara sudi wadani penyucian pindah agama upacara perkawinan bisa di lakukan dan sah menurut hukum adat bali.

Bagi masyarakat desa tangguwisia yang sudah melaksanakan perkawinan beda agama hendaknya perkawinan tersebut memiliki akte perkawinan, karena dengan memiliki akte perkawinan mnandakan sah nya perkawinan tersebut di mata hukum nasional.

Bagi generasi muda sebagai generasi penerus bangsa hendaknya mampu memikul beban warisan budaya nenek moyang dari jaman dahulu.

\section{DAFTAR PUSTAKA}

Arthayasa. Tahun 1998. Petunjuk Teknis Perkawinan Hindu. Penerbit Surabaya :Paramitha.

Burhan Bungin.2003.Metodologipenelitian kualitatif Jakarta:PT.Raja Pratindo.

Anonim 2004. Petunjuk Teknis Perkawinan Hindu. Surabaya :Paramitha

Manawa Dharma. Ditjen Bimas Hindu dan Budha. Departemen Agama Republik Indonesia,Jakarta.

Mulyana. 2004.Metodologi penelitian kuantitatif paradigma baru ilmu komunikasi dan ilmu sosiallainnya. Bandung: PT Rosdakarya

Netra,I.B.1974.Metodologi Penelitian. Singaraja : Biro Penelitian, Singaraja: Biro Penelitian Fakultas IImu Pendidikan Universitas Udayana. 
Pudja, Gde dan Tjok Rai Sudartha.2002.Manawa Dharma sastra.Weda smerti,kopedium Hukum Hindu. Jakarta: Yayasab Dharma Naradha .1978. Manawa Dharma. Ditjen Bimas Hindu dan Budha. Departemen Agama Republik Indonesia, Jakarta.

Sudarsono. 1994.Hukum Perkawinan Nasional.Jakarta: PT Rineka Cipta

.2003. Pengantar Hukum Indonesia. Jakarta:Rineka cipta.

Sudiatmaka, Ketut.2001.Materi pokok Hukum Adat Pada Jurusan Ppkn IKIP Negeri Singaraja. Singaraja.

Undang-Undang Nomor 1 Tahun 1974

Tentang Perkawinan dan Pengaturan Pemerintah Republik Indonesia Nomor 9 Tahun 1975 Tentang pelaksanaan Undang Undang Nomor 1 Tahun 1974. 